\title{
An Assessment of Risk Management Strategies for Financial Information Systems by Financial Institutions in Kenya
}

\author{
Ann Kibe ${ }^{1 *}$ Prof Waweru Mwangi ${ }^{1}$ Dr Stephen Kimani ${ }^{1}$ \\ School of Computing and IT, Jomo Kenyatta University of Agriculture and Technology, P O Box 62000-00200 \\ Nairobi Kenya
}

\begin{abstract}
Decision making is an important aspect of software processes management. Most organizations allocate resources based on predictions. Improving the accuracy of such predictions reduces costs and helps in efficient resources management. risk management is of vital importance for any financial institution (and enterprise for that matter) to keep its information systems secure at an acceptable level, the key issues focus on both how to reduce the probability of risk occurrence and decrease the loss of risk consequence. The main tasks for the implementation of such requirements involve the determination of the causes of risks, the estimation of risk occurrence probability, and the evaluation of risk consequence severity, which are all included in the risk analysis.

In the process of risk analysis for information systems, models are built in order to analyze and better understand the risk factors and their causal relationships in real-world information systems. Establishing an appropriate model suitable for the target risk problem is a crucial task that will ultimately influence the effectiveness of risk analysis results. In the existing literature, most the approaches either assumed that the structure of the model was provided by domain expert experience and knowledge, or assumed that the structure was chosen from some general well-known class of model structures, thus, the results of risk analysis were relatively subjective.

To overcome these drawbacks, not only expert have the experience and knowledge that needs to be taken into account, but also, the database of observed cases from information systems should be utilized in the process of modeling. With the growth of the dependency on IT, the impact of risk concerns on the development and exploitation of information systems has also increased exponentially. The risk management system focuses on specific phases of the software life cycle, without recognizing that risks in one stage can have an impact on other stages.

This paper explores the risk situation as it is in the financial institutions in Kenya and suggests ways through which risk management can be brought a notch higher in order to minimise the losses incurred when faced by these risk situations.
\end{abstract}

Keywords: Risks, risk analysis, risk management

\section{Introduction}

The researcher has used qualitative research approach. The qualitative research paradigm, also referred to as "constructivist", "naturalistic", "interpretative", "post-positivist" or "post-modern perspective" approach (Lincoln \&Guba, 2011 and Smith, 2011), is an enquiry process of comprehending a social or human problem/phenomenon based on building a complex holistic picture formed with words, reporting detailed views of informants and conduced in a natural setting (Creswell, 2010).

Qualitative research is multi method in focus, involving an interpretive, naturalistic approach to its subject matter. This means that qualitative researchersstudy things in their natural settings, attempting to make sense of, or interpret,phenomena in terms of the meanings people bring to them (Newman \& Benz2011). Qualitative approach is one in which the inquirer often makes knowledgeclaims based primarily on constructivist perspectives (i.e., the multiple meaning ofindividual experiences, meaning socially and historically constructed, with anintent of developing a theory or pattern) or advocacy/participatory perspectives(i.e., political, issueoriented, collaborative or change oriented) or both. It also uses strategies of inquiry such as narratives, phenomenology, ethnography, grounded theory studies or case studies.

\subsection{Research Design}

Creswell and Clark (2007) state that research designs are procedures for collecting, analysing, interpreting and reporting data in research studies. Rigorous research designs are important because they guide the methods and decisions that researchers must make during the study and set the logic by which interpretations are made at the end of the study.

The exploratory research design used has outlined the situation in respect to the variable being investigated. This means of research design makes it possible for data to be collected effectively without any manipulation on the 
research context. The research design seeks to outlay the goals of the research by stipulating practical issues that are of focus to this study (Saunders et al, 2009).

Research can be classified in terms of its purpose. Accordingly, it is most often classified as exploratory, descriptive or explanatory (Saunders, Lewis\&Thornhill 2003). The researcher has opted to use exploratory research. Exploratory research is used to develop a better understanding (Hair,Babin, Money\&Samouel 2003). Exploratory studies are a valuable means of finding out what is happening, to seek new insight, to ask questions and to assessphenomena in a new light. It is particularly useful if researcher wish to clarify theunderstanding of a problem. There are three principle ways of conductingexploratory research: a search of the literature, talking to experts in the subject,conducting focus group interviews (Saunders, Lewis \&Thornhill2003).

\subsection{Population of the Study}

The target population consisted of employees of various financial institutions, with background knowledge of FIS and risk management by virtue of their positions in their organizations be it managerial or administrative. They include directors, manager, unit and departmental heads.

1.2.1 Sampling Frame

To facilitate data collection, the study's sampling frame constituted a listing of institutions from various sectors which include: banks, SACCOs and micro finance institutions. There were a total of 40 respondents from various financial institutions.

\subsubsection{Sample and Sampling Technique}

An adequate sample size should allow reliability of results so that the investigation can be repeated with consistent results. A sample is a small set of data drawn from a population as Leishman (2008) noted that the sample should be sufficiently and demonstrably representative of the population in order to allow analysis of the sample to be used. The sample size affects confidence interval, thus could, in principle, select the sample to yield any degree of confidence (Doodley, 1995). For this study, a stratified purposive sampling technique was adopted for data collection from the sampled intuitions and key informants; since financial institutions are discrete and in an effort to maintain confidentiality of the respondents. This is normally done by dividing the population into different strata on the basis of some common characteristics.

\section{Data Collection}

Because surveys make it possible to study a population too large to observe directly, it presents an excellent mechanism to collect original data. According to Babbie and Mouton (2001: 232), the careful selection of a probability sample will provide a group of respondentswhose characteristics could mirror those of the larger population. The data gathered bystudying the characteristics of the sample can then be generalised to the larger population. This data is then gathered by administering a questionnaire, otherwise known as a structured scheduled interview. Bradburnet al. (2004: 360) define a questionnaire as "the complete data collection instrument used by and interviewer or respondent (or both) during asurvey.

Primary data was used for this study and the data was collected using questionnaires that were hand delivered and also sent by e-mail.A questionnaire was prepared to understand the perspective of various financial IS stakeholders on risk management including the use of Bayesian networks. The questionnaire was designed as per the objectives of the study.

Secondary data was also used. Information was obtained from various journals, publications, websites and reports. Secondary sources helped the researcher in explaining different conclusions based on previous studies that have been conducted and concluded, while the primary data sources was information collected by the researcher herself specifically for the study (Pervez \&Kjell 2005).

\subsection{Validity and Reliability of the Instrument}

In order to reducing the possibility of getting the answer wrong, attention need to be paid two particular on research design: reliability and validity (Saunders et. al., 2003). Validity is concerned with whether the findings are really about what they appear to be about (Saunders et. al., 2003). Validity defined as the extent to which data collection method ormethods accurately measure what they were intended to measure (Saunders et. al., 2003). Yin (2003) states, "no single source has a complete advantage over all others". The different sources are highly complementary, and a good case study should use as many sources as possible.The validity of scientific study increases by using various sources of evidence(Yin, 2003).

For quality control, a pre-test of the research instruments to establish their validity was done. The instrument was given to individuals (who constitute the population of key informants) to give their opinion on the relevance of the questions using a 4-point scale of relevant, quite relevant, somewhat relevant, and not relevant.Data is measured in order to have relevance and validity for the issue that is examined. In this study the researcher will say that the theoretical understanding of risk management of information systems is the same as in the operational sense and to that extent, there is clear connection between the theoretical and practical notion 
of risk management of information systems and for that reason can say that she had valid data. Additionally, numerous steps were taken to ensure the validity of the study: Data was collected by in-depth questionnaires from the reliable sources with knowledge of financial information systems risk management

- Questions in the questionnaire were made based on literature review and frame of reference to ensure the validity of the result.

- Data has been collected through between 4 weeks, within this short period of time no major event has been changed with the related topic.

According to Saunders et. al., 2003, reliability refers to the degree to which data collection method or methods will yield consistent findings, similar observations would be made or conclusions reached by other researchers or there is transparency in how sense was made from the raw data.Reliability can be assessed by the following three questions (Easterby-Smith et al., 2002: p.53):Numbers of different steps were taken to ensure the reliability of the study:

- The same type of questions was used for all the respondents in order to increase the reliability.

- The theories that have been selected for the study was clearly described and research question has been formulated based on the previous theory.

- Data has been collected based on the frame of reference that was drawn from the discussed theories. The objective is to make sure that if another investigator will follow the same procedures and used the same case study objects, the same conclusions would be made.

\subsection{Ethical Consideration}

The goal of ethics in research is to ensure that no one is harmed or suffers adverse consequences from the research activities (Cooper and Schindler, 2001). The researcher has undertaken various measures to protect the rights of the respondents by:

- Ensuring that none of the respondents was named during the research or subsequent report

- Respondents were selected to participate without compulsion

- All respondents were informed of the reason and purpose of the research; and

- Informed consent was sought from the management of the selected company and the respondents before the commencement of this research initiative.

\section{Data Processing and Analysis}

As mentioned in the methodology primary data was collected using questionnaires that were formulated based on the knowledge gathered from secondary sources to help attain the objectives of the research. This section states the objectives and how they were obtained in the research.

Demographic factors

They survey setting was Financial institutions composed of a listing of various financial institutions in the industry.

Figure 1: In which financial industry sector is your company?

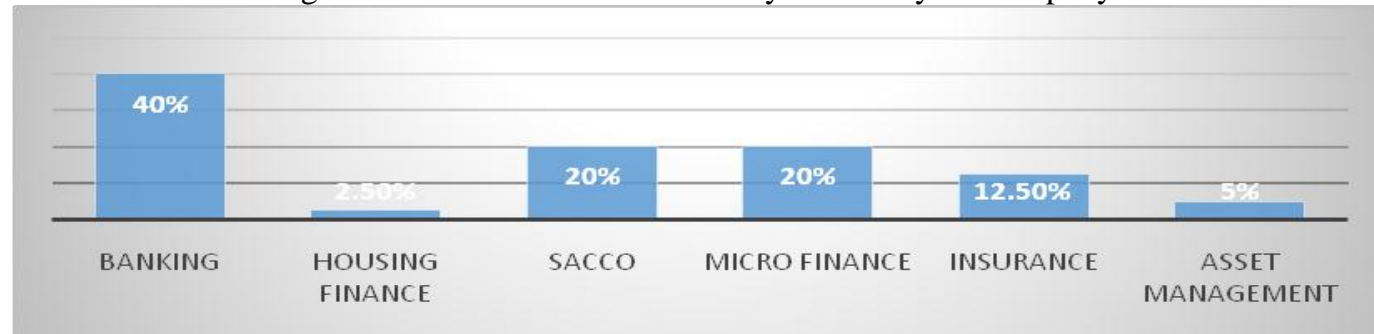

The survey sample was selected on the basis of their organizational position; by this virtue they were better placed to have knowledge and access to provide accurate information required in this research.

Figure 2: Which of the following best describes your title?

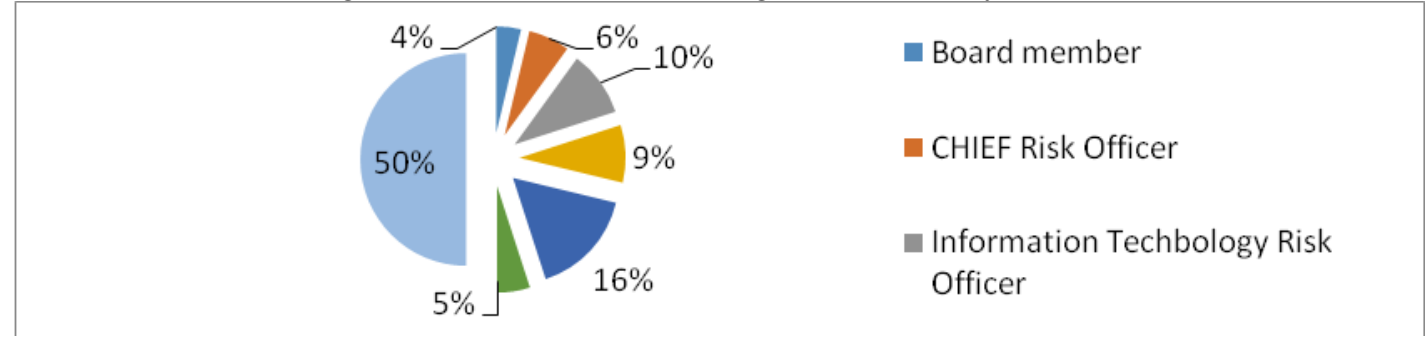

Financial Information Systems Acquisition

The researcher sought to find out how financial institutions acquired their Financial Information Systems. 
When in need of Financial Information systems, my company ......

\begin{tabular}{lll}
\hline & Frequency & Percent \\
\hline Tailor makes the system (internally or outsources) & 24 & 60.0 \\
Acquires already developed systems & 16 & 40.0 \\
Total & 40 & 100.0 \\
\hline
\end{tabular}

As shown in table 1 above, $60 \%$ of financial institutions in Kenya develop their own tailor made financial information Systems; this is done by their employees or outsourced developers as opposed to $16 \%$ of the institutions which acquire already developed information systems.

Organizations' involvement in Information System Development

Organization's involvement in Information systems development is vital not only to ensure successful implementation but also to manage risks. The respondents for organizations that tailor made their Financial Information systems were asked whether they were actively involved in every stage of their financial information system development.

Table 2: In the case of tailor made systems, is your organization actively involved in every stage of the information system development?

\begin{tabular}{lll}
\hline & Frequency & Percent \\
\hline Yes & 14 & 58.33 \\
No & 7 & 29.17 \\
Don't know & 3 & 12.50 \\
Total & 24 & 100.0 \\
\hline
\end{tabular}

More than half $(58.33 \%)$ of these organizations were actively involved in their information systems development, a significant $29.17 \%$ of the organizations were not actively involved while $12.5 \%$ of the respondents had no idea about their organizations involvement.

Organizations that are not actively involved in their information systems development have a higher chance of being exposed to not only more risks that could have been well managed in the initial stages, but also incur more cost in mitigating the said risks.

Table 3: Do you agree that financial institutions are sufficiently actively involved in the development of their

\begin{tabular}{lll} 
& information systems? \\
\hline Strongly agree & Frequency & Percent \\
Agree & 10 & 25.0 \\
Neither Agree nor Disagree & 21 & 52.5 \\
Disagree & 3 & 7.5 \\
Total & 6 & 15.0 \\
\hline
\end{tabular}

The survey indicated that majority of the respondents $77.5 \%$ felt that their organizations were sufficiently actively involved in the development of their information systems, percentage $22.5 \%$ were either not sure or felt that involvement was insufficient.

Financial Information System Development Risks

Figure 3: Based on your experience and professional knowledge please indicate the risk levels in the following information systems development environments.

\section{i. Development cycle risks}

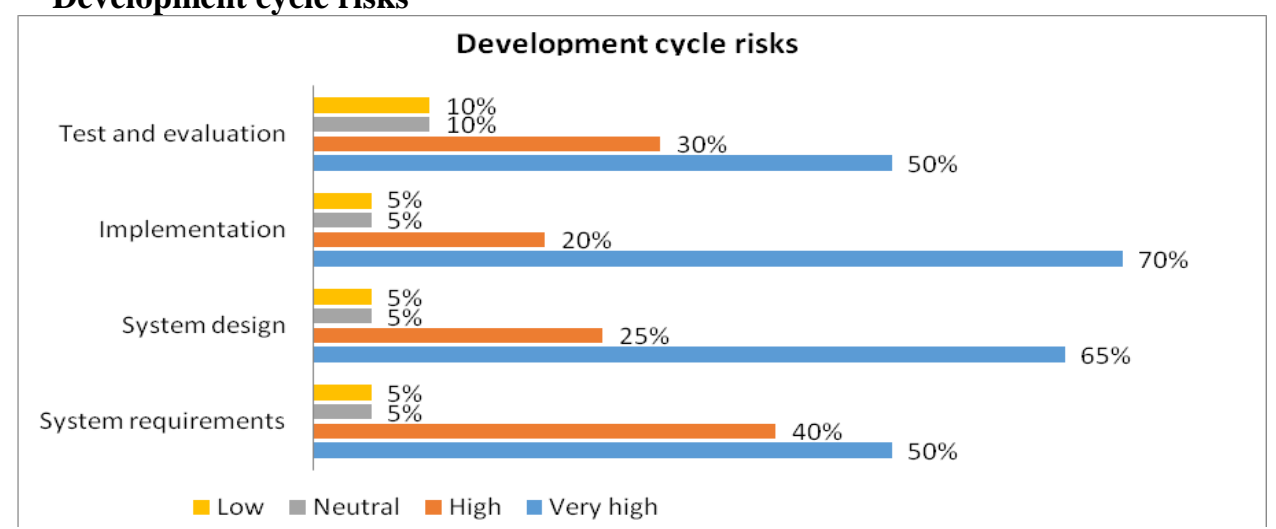

Majority of the respondents $70 \%$ indicated that the implementation stage of the IS development cycle had the 
highest risk level followed by system design and test and evaluation (both at 50\%).

ii. Development environment risks

Work environment was considered by $55 \%$ of the respondents to be posing the highest risk as far as

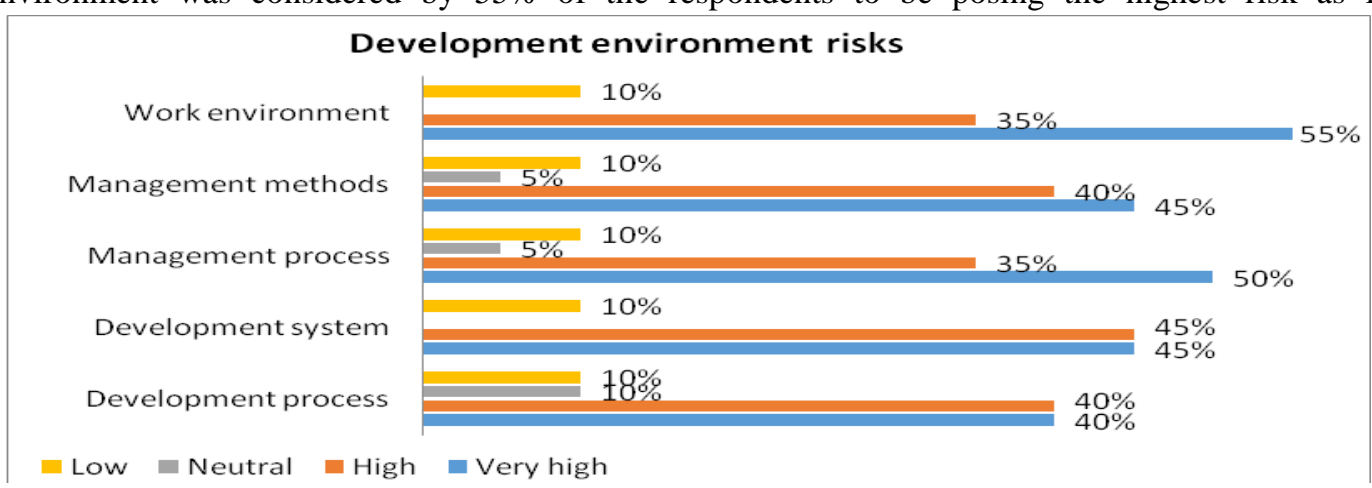

development environment risks were concerned followed closely by management process $50 \%$.

iii. Programmatic Risks

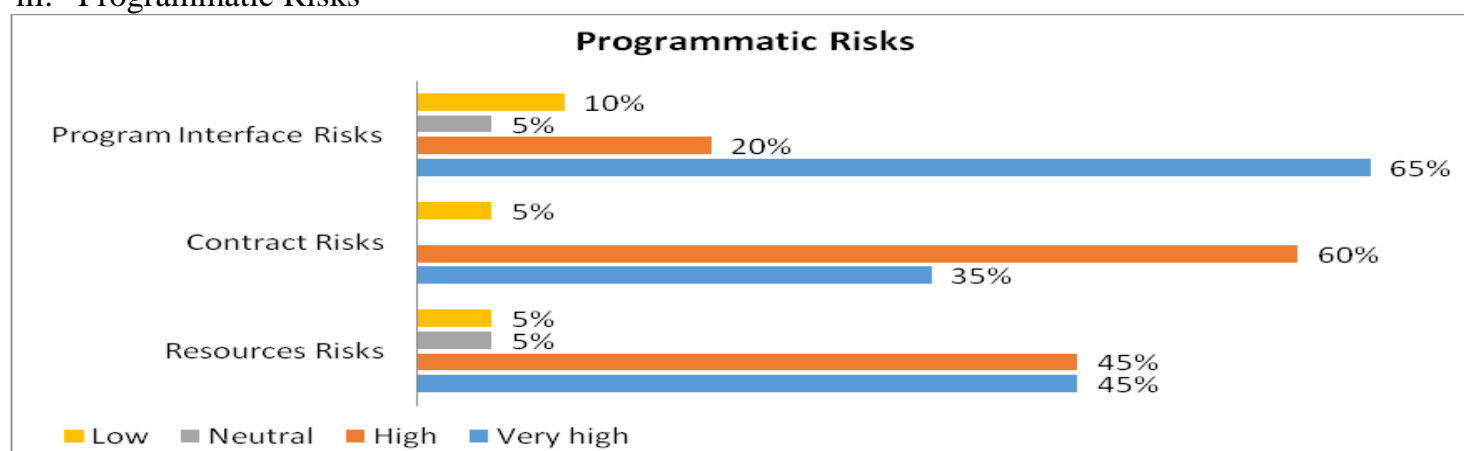

Program interface risks and contract risks were considered to pose high risk levels by most respondents (65 and $60 \%$ ) respondents, resources risks also were also considered to pose significant risk levels.

Financial Information Systems Risk Management Program: Maturity, Effectiveness and challenges

The maturity of financial information system risk program not only comprehensively presents its structured risk profile but also determines its efficiency and effectiveness. A mature and effective risk management should be able to define the organizations' risk, risk exposure, risk appetite and strengths and weaknesses for optimum risk management.

FIGURE 4: What impact has each of the following had on your company's information systems risk management program over the past 2 years? Check one alternative per category.

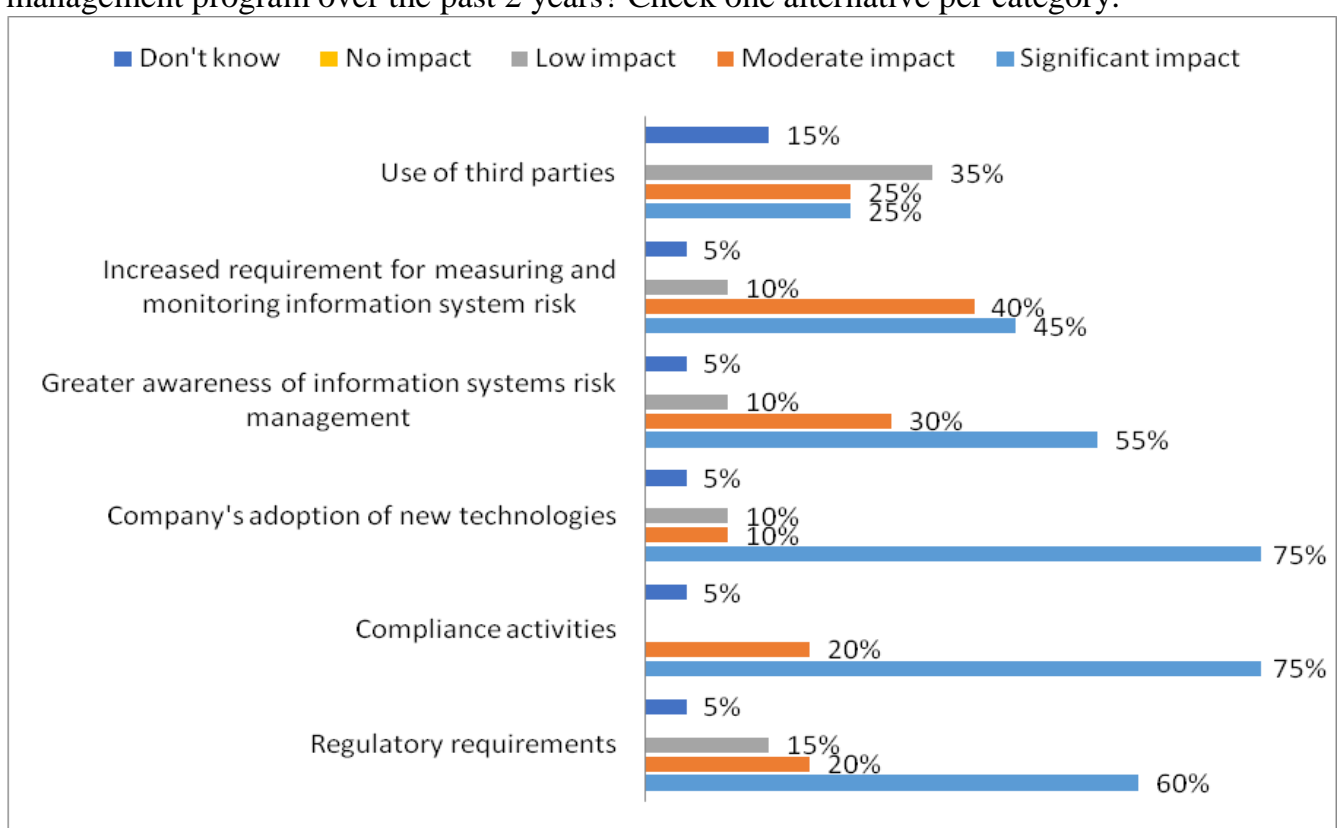

The figure 4: indicates that majority of the respondents $(75 \%)$ believe that company's adoption of new technologies and compliance activities have significant impact on information system risk management. Use of 
third parties, was regarded as to have the least impact by $35 \%$ of the respondents. Regulatory requirements was believed by $60 \%$ of the respondents as to have significant impact, this together with compliance drivers $(75 \%)$ suggests a need to increase awareness of and education about the broader business benefits of an information system risk management program. Financial Information system risk management should be viewed as more than just a way to keep an organization out of regulatory trouble. Awareness and education can be used to convey an organization's information risk management purpose, and objectives, which, in turn, helps employees become more aware of their roles in managing risk.

FIGURE 5: Have the following factors posed a challenge to, or contributed to the success of, your company's financial information systems risk management initiatives in the 2 years?

$$
\begin{aligned}
& \text { Staff resources to support information system risk } \\
& \text { management }
\end{aligned}
$$

Financial investment to support information system risk management

Technology tools to support information system risk management

Documented information system risk management strategy

Tools to monitor and report risk

Multiple risk assessments

Level of risk tolerance

Competing objectives

Integrated approach to risk management

Don't know $\begin{array}{llllllllll}0 \% & 10 \% & 20 \% & 30 \% & 40 \% & 50 \% & 60 \% & 70 \% & 80 \% & 90 \%\end{array}$

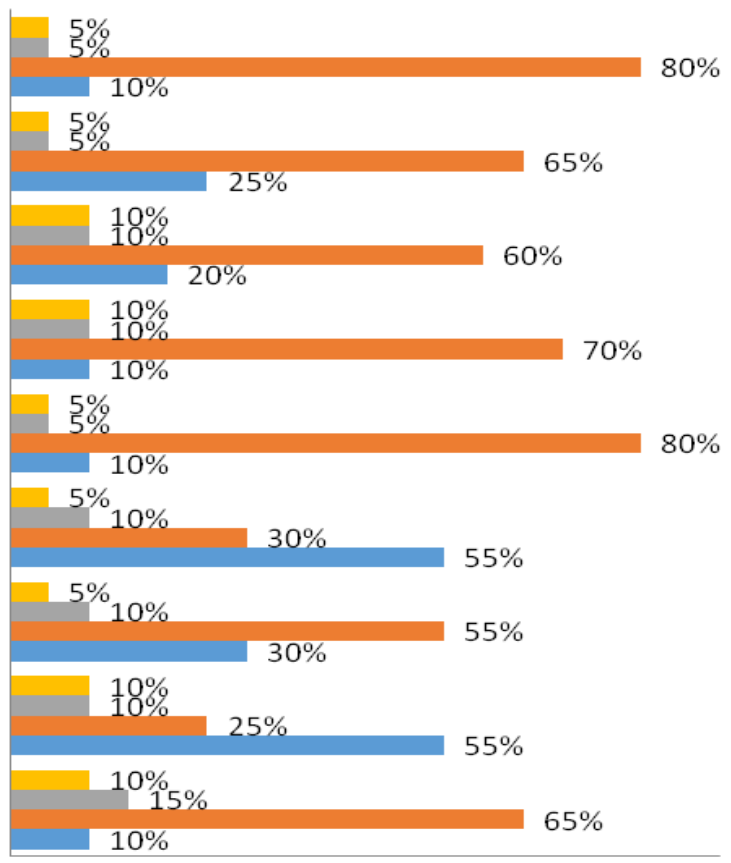

Staff resources to support information system risk management and tools to monitor and report risk were attributed by $80 \%$ of the respondents as major contributing factors to the success of their company's financial information systems risk management initiatives. Other significant key success factors included; Documented information system risk management strategy (70\%), integrated approach to risk management $(65 \%)$ and financial investment to support information system risk management $(65 \%)$.

The existence of multiple risk assessments and competing objectives were regarded by $55 \%$ of the respondents as major factors posing challenge to the success of their company's financial information systems risk management initiatives.

Factor analysis was used to determine the factors that are highly related in respect to posing a challenge or contributing to success of the organization.

\begin{tabular}{|c|c|c|c|c|c|c|}
\hline & & $\begin{array}{l}\text { coordinating } \\
\text { risk and } \\
\text { compliance } \\
\text { activities }\end{array}$ & $\begin{array}{l}\text { optimization } \\
\text { of controls }\end{array}$ & $\begin{array}{l}\text { use of } \\
\text { technology to } \\
\text { manage risk }\end{array}$ & $\begin{array}{l}\text { risk reporting } \\
\text { and } \\
\text { disclosure }\end{array}$ & $\begin{array}{l}\text { alignment with } \\
\text { corporate risk } \\
\text { management }\end{array}$ \\
\hline \multirow{5}{*}{ Correlation } & $\begin{array}{l}\text { (1) coordinating risk and } \\
\text { compliance activities }\end{array}$ & 1.000 & .147 & -.046 & .000 & -.021 \\
\hline & (2) optimization of controls & .147 & 1.000 & .183 & -.256 & .017 \\
\hline & $\begin{array}{l}\text { (3) use of technology to } \\
\text { manage risk }\end{array}$ & -.046 & .183 & 1.000 & .081 & -.155 \\
\hline & $\begin{array}{lrr}(4) & \text { risk } & \text { reporting } \\
\text { disclosure } & & \end{array}$ & .000 & -.256 & .081 & 1.000 & .360 \\
\hline & $\begin{array}{l}\text { (5) alignment with corporate } \\
\text { risk management }\end{array}$ & -.021 & .017 & -.155 & .360 & 1.000 \\
\hline
\end{tabular}

Correlation Matrix 
Total Variance Explained

\begin{tabular}{|l|l|l|l|l|l|l|}
\hline Component & Initial Eigenvalues & \multicolumn{3}{|l|}{ Extraction Sums of Squared Loadings } \\
\cline { 2 - 7 } & Total & $\begin{array}{l}\% \\
\text { Variance }\end{array}$ & $\begin{array}{l}\text { Cumulative } \\
\%\end{array}$ & Total & $\%$ of Variance & Cumulative \% \\
\hline 1 & 1.470 & 29.409 & 29.409 & 1.470 & 29.409 & 29.409 \\
2 & 1.119 & 22.386 & 51.796 & 1.119 & 22.386 & 51.796 \\
3 & 1.078 & 21.554 & 73.350 & 1.078 & 21.554 & 73.350 \\
4 & .893 & 17.856 & 91.206 & & & \\
5 & .440 & 8.794 & 100.000 & & & \\
\hline
\end{tabular}

Extraction Method: Principal Component Analysis.

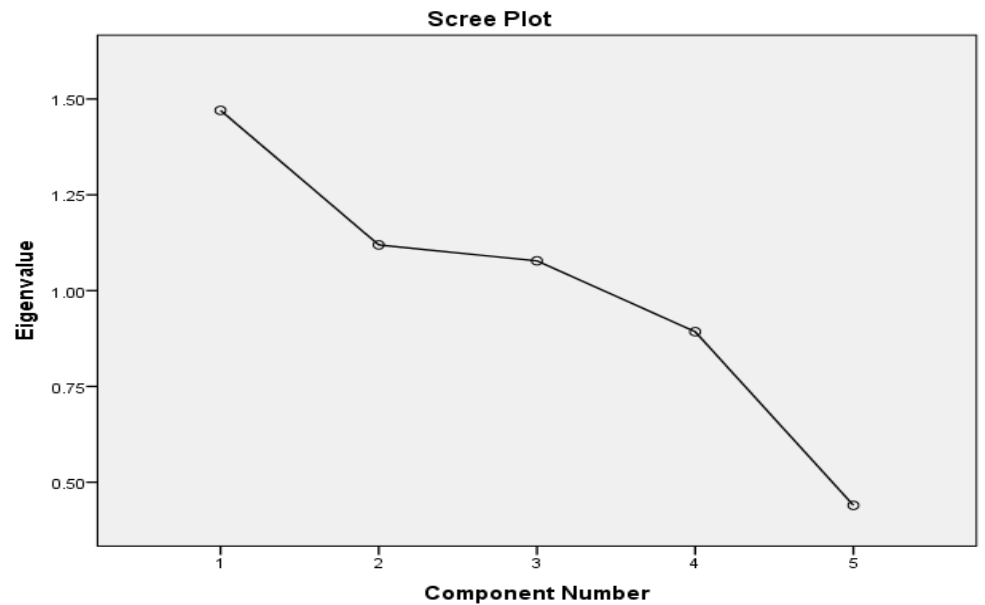

Component Matrix ${ }^{\mathrm{a}}$

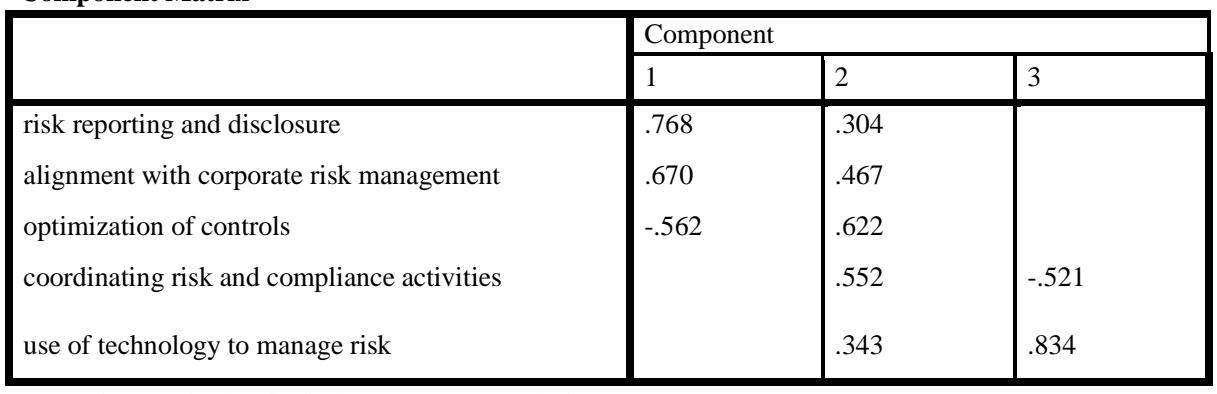

Extraction Method: Principal Component Analysis.

a. 3 components extracted.

The above data was used to determine the factors that are highly correlated. According to the total variance explained by the component matrix table, the researcher retained three factors with an Eigen value greater than 1. The total variance explained table and the scree plot show the total number of variables to be retained after rotation. According to the component matrix table, factor 1, 2 and 3 are highly correlated. (1. Coordinating risk and compliance activities 2. optimization of controls 3. use of technology to manage risk). The total variance explained by the three factors is $73.35 \%$.

Financial Information Systems Risk program Investment and Governance

When asked about investments in information system risk management, $50 \%$ of respondents felt their organizations would increase spending over the next 2 years, while the other half were of the opinion that investment would increase by between $5-25 \%$.

As a program becomes more effective and efficient, it should not require substantially increased investment every year, except in the event of significant business or regulatory changes. Ideally, spending should level off and may even decrease as a program gains maturity and is optimized. This increase in investment however is an indication that most programs are only in the early stages of maturity since investments typically increase at higher rates when a program is in development. 
Table 4: By what percentage estimate do you think your company's financial investment in financial information systems risk management activities will change over the next two years?

\begin{tabular}{lll}
\hline & Frequency & Percent \\
\hline Increase by 5-25\% & 20 & 50.0 \\
Increase by more than $25 \%$ & 20 & 50.0 \\
Total & 40 & 100.0 \\
\hline
\end{tabular}

Governance provides a strategic approach to developing and maintaining an information systems risk management program. In a properly governed program, resources and spending are focused on formalizing the program and processes as well as on strengthening the alignment among risk functions prior to investing time and resources in technology solutions.

Strong governance of an information technology risk management program is critical to ensure that the program is aligned with the business's goals and clearly demonstrate show it supports the overall objectives of the business. The goal is to make certain that investments are focused on the right areas, based on the maturity and current state of the program, as well as to validate that the return on investment is properly tracked and reported.

Figure 6: How will your company's investment in information system risk management be allocated toward the following initiatives?

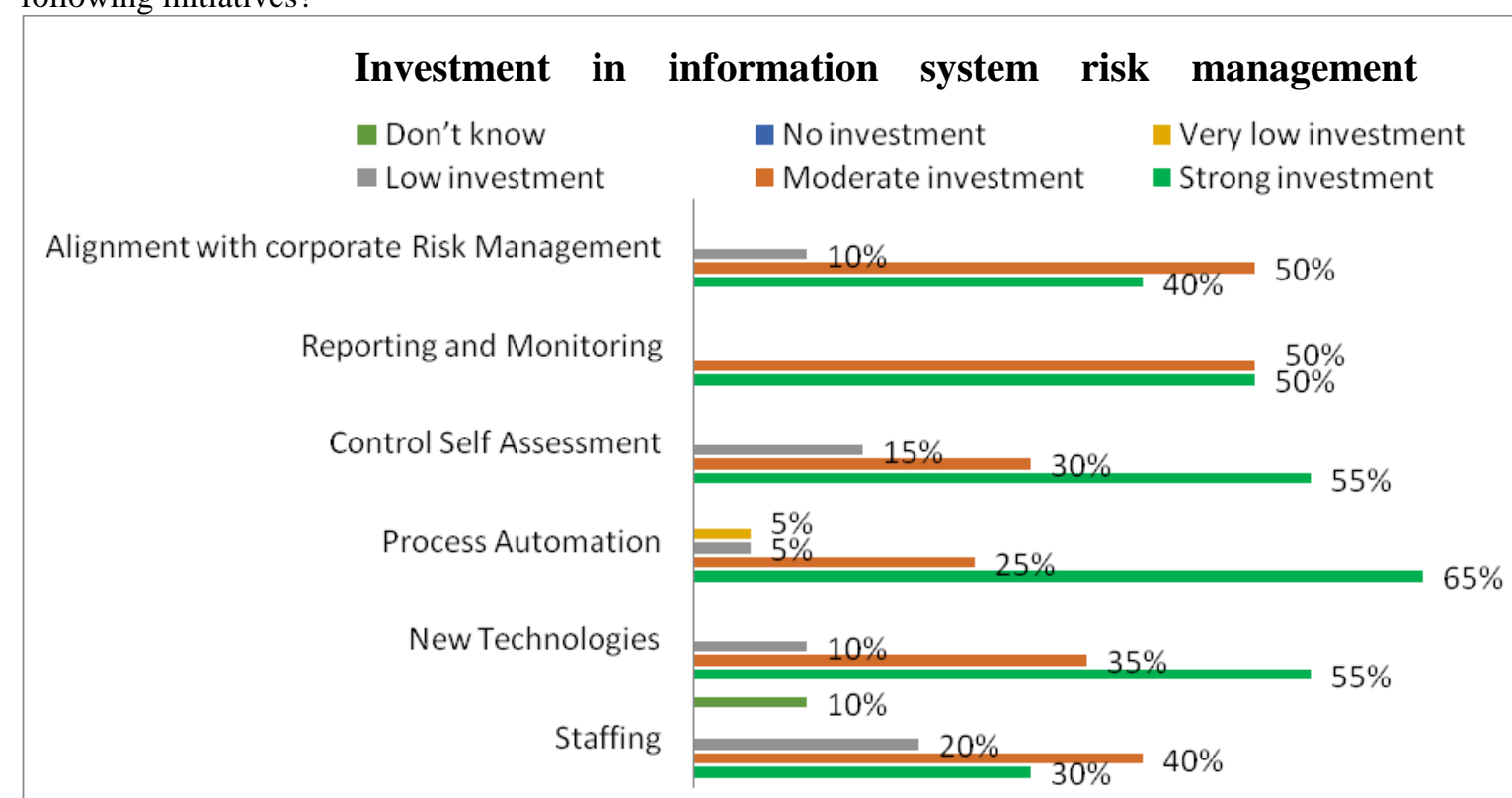

The survey indicates that process automation would receive strong investment in the organization; this was represented by $65 \%$ of the total respondents. Following closely was new technologies and control selfassessment. Additionally, the initiative that would receive the lowest investment the company's information system investment in risk management is concerned is staffing.

The survey indicates that $80 \%$ to $90 \%$ of the organizations are managing and/or monitoring most critical risk areas. As future plans are formed, considering the appropriate balance between monitoring and managing risk will be key decision points in improving efficiencies within the program.

The high investment in new technologies and process automation as tools and technology initiatives designed to optimize the existing processes shows us that there is a strong interest in investing in tools and technology for process automation and optimization. Also the survey shows that $10 \%$ of the respondents do not have a formalized information technology risk management function and that there are programs that still need better alignment with other, broader risk functions.

Financial Information Systems Risk Management Process

To what extent is your company's approach to financial information system risk management aligned with the enterprise risk management strategies and frameworks? Financial information systems and enterprise risk management are ... 


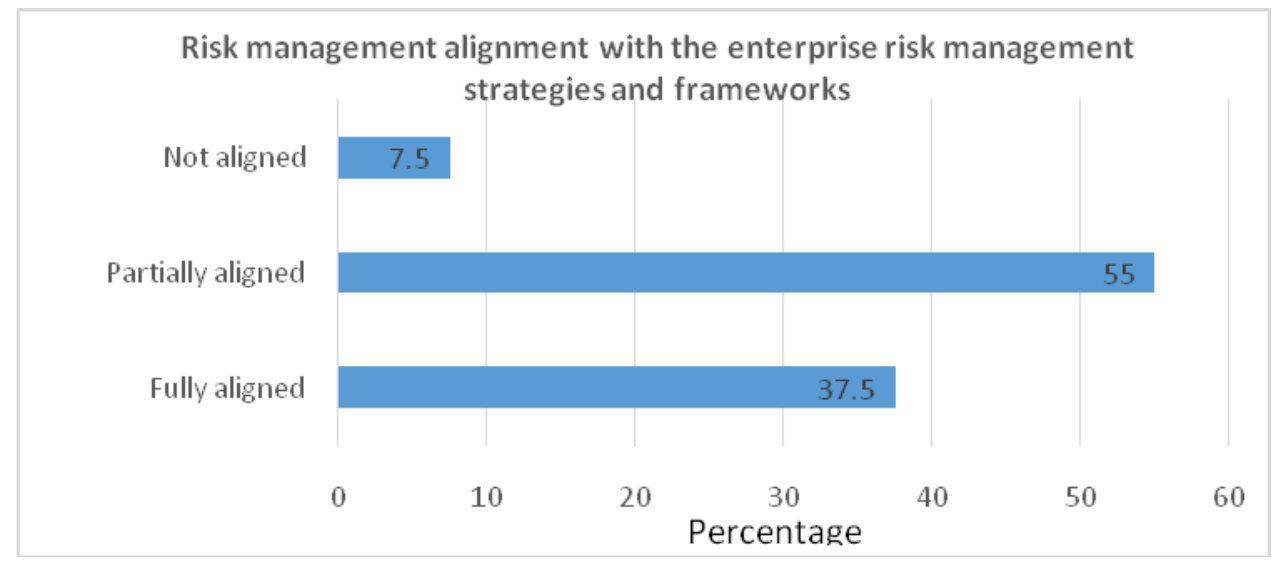

Financial information system risk management of $55 \%$ of the organisations according to the respondents are partially aligned with their enterprise risk management strategies and frameworks, while $37.5 \%$ are partially aligned, the rest $7.5 \%$ are not aligned

Figure7: Which of the following risk areas does your organization manage or monitor within the scope of the financial information systems risk management function? Select all that apply.

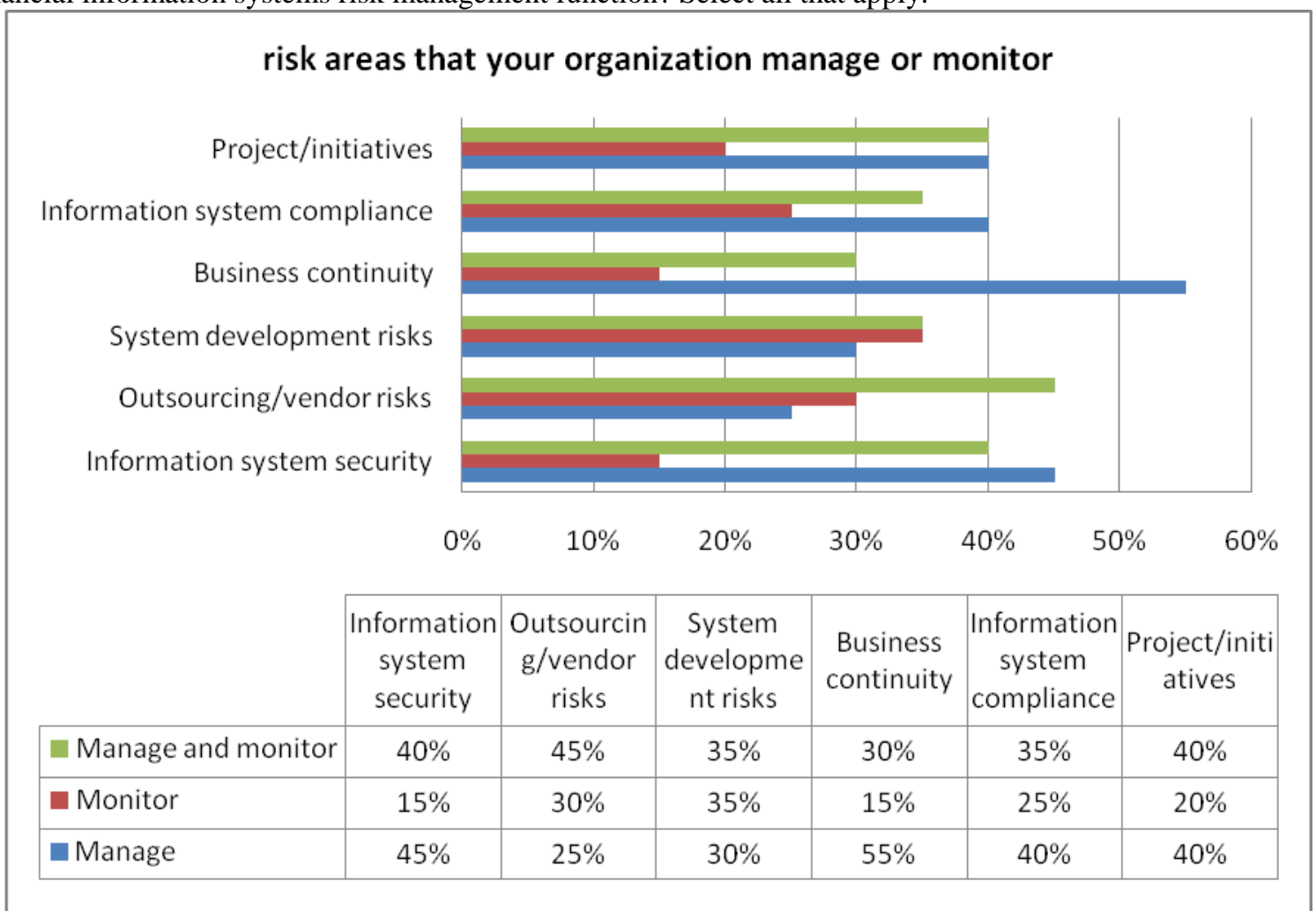

Majority of the financial institutions surveyed 55\% manage their business continuity, the most monitored area is system development risks albeit by only $35 \%$ of the organizations while outsourcing/vendor risks is managed and monitored by most organizations according to $45 \%$ of the respondents.

\section{Formalization}

There is a positive trend as far as financial information system risk management is concerned seeing as formalization of the various organizations risk management programs are underway; also these organizations are increasing their investments in risk management programs, program governance and budgetary allocations however needs improvement.

Organizations involvement should not only stop after system implementation, users of any information system pose or expose the system to various risks. As such an effective risk management system should involve all users in risk management in the entire financial information system life cycle to ensure maximum benefit to the organization. The researcher sought to find out if this was the case; 
Table 5: Are you involved in financial information systems risk management in your company?

\begin{tabular}{lll}
\hline & Frequency & Percent \\
\hline Yes & 28 & 70.0 \\
No & 12 & 30.0 \\
Total & 40 & 100.0 \\
\hline
\end{tabular}

Majority of the respondents $70 \%$, were actively involved in risk management, although this is a positive trend, the level of involvement is however also crucial.

The survey indicated that $90 \%$ of the organizations have a formal financial information system risk framework and assessment process in place.

Table 6: Please indicate the extent to which you agree with this statement: My company has formal and clearly defined roles and responsibilities (mandate) for the information system risk function.

\begin{tabular}{lll}
\hline & Frequency & Percent \\
\hline Strongly agree & 22 & 55.0 \\
Agree & 14 & 35.0 \\
Neither agree nor disagree & 4 & 10.0 \\
Total & 40 & 100.0 \\
\hline
\end{tabular}

Most financial institutions have formal and clearly defined roles and responsibilities (mandate) for information system risk function as evidenced by $90 \%$ of the respondents, however $10 \%$ were unsure of the existence of such a structure in their organization.

Figure 7: Does your company have a formal financial information system risk framework and assessment process in place?

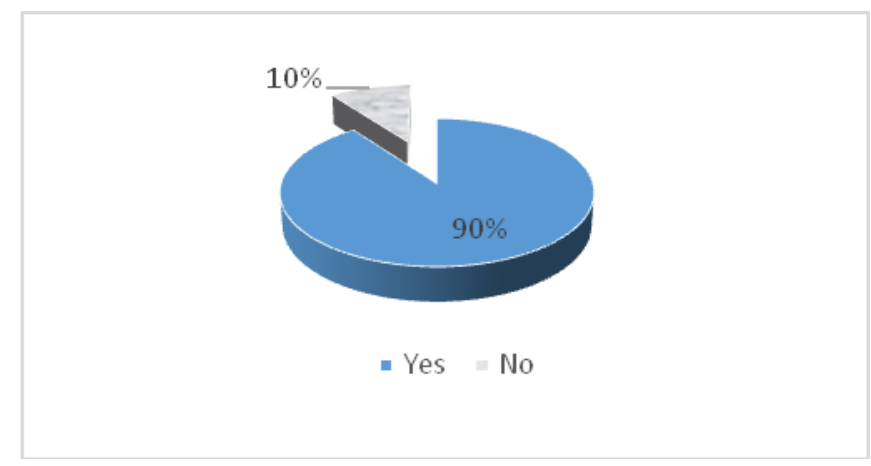

Many organizations $90 \%$ have formalization of their financial information system risk framework and assessment process including their programs, roles and responsibilities, policies and procedures; mostly from around the time of system implementation.

Table 7: Please indicate the extent of your agreement with the following statement: There is a common risk language that is broadly used and understood throughout and across my sector (e.g. banking, insurance).

\begin{tabular}{lll}
\hline & Frequency & Percent \\
\hline Strongly agree & 20 & 50.0 \\
Agree & 14 & 35.0 \\
Neither agree nor disagree & 4 & 10.0 \\
Disagree & 2 & 5.0 \\
Total & 40 & 100.0 \\
\hline
\end{tabular}

According to the survey responses, $85 \%$ of the respondents said there is a common risk language that is broadly used, understood and accepted. However, $10 \%$ of the respondents were not sure if one existed while 5\% said there was no common risk language thatwas broadly accepted and understood throughout their sector.

Table 8: Does your company have a formal financial information system risk framework and assessment process in place?

\begin{tabular}{lll}
\hline & Frequency & Percent \\
\hline Yes & 34 & 85.0 \\
No & 4 & 10.0 \\
Don't Know & 2 & 5.0 \\
Total & 40 & 100.0 \\
\hline
\end{tabular}

From the survey, $85 \%$ of the respondents stated that there existed a formal financial information system risk 
framework and assessment process, $5 \%$ were not sure and $10 \%$ said it did not exist

We can therefore conclude that, although there may be frameworks in place, they are missing the common risk language that is a critical program component to improve the efficiencies and effectiveness needed to achieve a consistent risk framework.

Tools and Technology

FIGURE 8: Have the following factors posed a challenge to, or contributed to the success of, your company's financial information systems risk management initiatives in the 2 years?

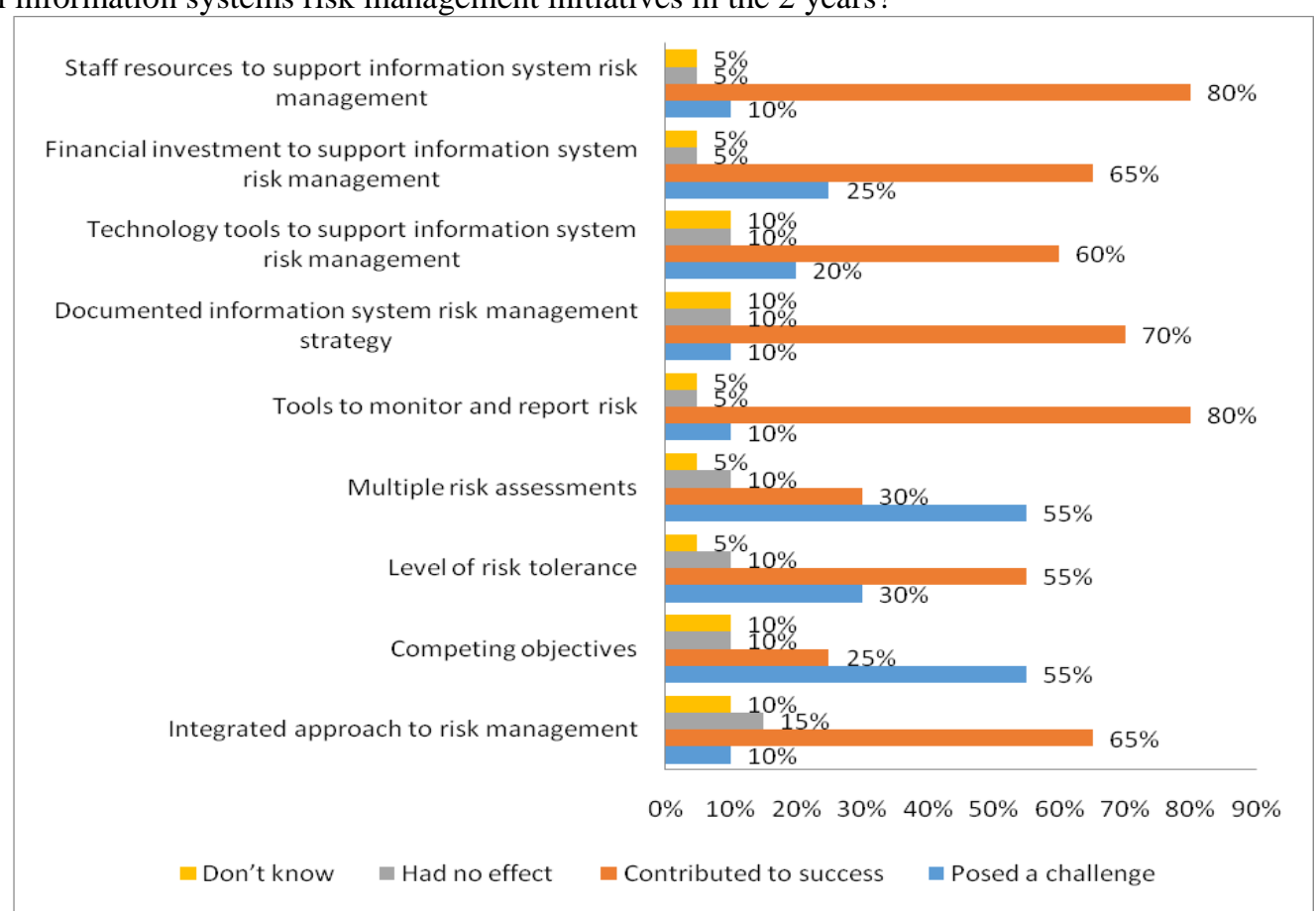

Reporting and Metrics

Reporting and metrics undoubtedly have a great impact in demonstrating the value that an information system risk management program brings to an organization. However, reporting functionality is largely reliant on tools and technology. An organization's process must be accurately mapped and effectively designed if the tools are to have a positive impact. Tools are not a solution in and of themselves; rather, they simply optimize an operational process and make it more efficient.

TABLE 8: Please indicate the extent of your agreement with the following statement: Information Systems Managers within my company receive sufficiently regular and robust information on risk from the company's information technology risk management teams.

\begin{tabular}{lll}
\hline & Frequency & Percent \\
\hline Strongly agree & 22 & 55.0 \\
Agree & 16 & 40.0 \\
Disagree & 2 & 5.0 \\
Total & 40 & 100.0 \\
\hline
\end{tabular}

According to the survey $95 \%$ of the respondents agree and strongly agree that have sufficient information to assess whether the information provided on risk is sufficient.

Table 9: Does your company have defined financial information system risk performance framework and metrics that are monitored and reported to management on a regular basis?

\begin{tabular}{lll}
\hline & Frequency & Percent \\
\hline Yes & 29 & 72.5 \\
No & 8 & 20.0 \\
Don't Know & 3 & 7.5 \\
Total & 40 & 100.0 \\
\hline
\end{tabular}

Majority of the respondents $72 \%$ said their organizations had defined financial information system risk performance framework and metrics that are monitored and reported to management on a regular basis while $20 \%$ did not, also $3 \%$ of the respondents were not sure whether or not their organizations had such a framework and metrics. 


\begin{tabular}{|c|c|c|c|c|c|}
\hline & & \multicolumn{3}{|c|}{$\begin{array}{l}\text { Effectiveness of company at coordinating } \\
\text { risk and compliance activities }\end{array}$} & \multirow[t]{2}{*}{ Total } \\
\hline & & \begin{tabular}{|l|} 
Highly \\
effective
\end{tabular} & $\begin{array}{l}\text { Effectiv } \\
\mathrm{e}\end{array}$ & $\begin{array}{l}\text { Moderately } \\
\text { effective }\end{array}$ & \\
\hline \multirow{4}{*}{$\begin{array}{l}\text { defined } \\
\text { information system rinancial } \\
\text { performance framework } \\
\text { and metrics that are } \\
\text { monitored and reported to } \\
\text { management on a regular } \\
\text { basis }\end{array}$} & Count & 16 & 14 & 2 & 32 \\
\hline & \begin{tabular}{|l|}
$\%$ within \\
yes
\end{tabular} & $88.9 \%$ & $70.0 \%$ & $100.0 \%$ & $80.0 \%$ \\
\hline & Count & 2 & 6 & 0 & 8 \\
\hline & $\begin{array}{|ll|}\% & \text { within } \\
\text { no } & \\
\end{array}$ & $11.1 \%$ & $30.0 \%$ & $0.0 \%$ & $20.0 \%$ \\
\hline \multirow{2}{*}{ Total } & Count & 18 & 20 & 2 & 40 \\
\hline & & $100.0 \%$ & $100.0 \%$ & $100.0 \%$ & $100.0 \%$ \\
\hline
\end{tabular}

Chi-Square Tests

\begin{tabular}{|l|l|l|l|}
\hline & Value & $\mathrm{df}$ & $\begin{array}{l}\text { Asymp. Sig. (2- } \\
\text { sided) }\end{array}$ \\
\hline $\begin{array}{l}\text { Pearson Chi-Square } \\
\text { Likelihood Ratio }\end{array}$ & $2.639^{\mathrm{a}}$ & 2 & .267 \\
Linear-by-Linear & .040 & 2 & .219 \\
Association & .645 & 1 & .422 \\
N of Valid Cases & 40 & & \\
\hline
\end{tabular}

a. 4 cells $(66.7 \%)$ have expected count less than 5 . The minimum expected count is .40 .

Chi-square statistics were used to determine whether there is a significant relationship between companies that have defined financial information system risk performance framework and metrics that are monitored and reported to management on a regular basis and effectiveness of the company at coordinating risk and compliance activities. It was established from the chi-square results that there was no significant relationship between these variables.

\begin{tabular}{|c|c|c|c|c|c|c|}
\hline & & \multicolumn{4}{|c|}{ Effectiveness of company at optimization of controls } & \multirow[t]{2}{*}{ Total } \\
\hline & & \begin{tabular}{|l|}
$\begin{array}{l}\text { Highly } \\
\text { effective }\end{array}$ \\
\end{tabular} & Effective & Moderately effective & Ineffective & \\
\hline \multirow{4}{*}{$\begin{array}{l}\text { defined financial information } \\
\text { system risk performance } \\
\text { framework and metrics that are } \\
\text { monitored and reported to } \\
\text { management on a regular basis }\end{array}$} & Count & 8 & 22 & 0 & 2 & 32 \\
\hline & $\%$ within yes & $80.0 \%$ & $84.6 \%$ & $0.0 \%$ & $100.0 \%$ & $80.0 \%$ \\
\hline & \begin{tabular}{|l|} 
Count \\
\end{tabular} & 2 & 4 & 2 & 0 & 8 \\
\hline & $\%$ within no & $20.0 \%$ & $15.4 \%$ & $100.0 \%$ & $0.0 \%$ & $20.0 \%$ \\
\hline \multirow{2}{*}{ Total } & Count & 10 & 26 & 2 & 2 & 40 \\
\hline & & $100.0 \%$ & $100.0 \%$ & $100.0 \%$ & $100.0 \%$ & $100.0 \%$ \\
\hline
\end{tabular}

\begin{tabular}{|l|l|l|l|}
\hline & Value & df & $\begin{array}{l}\text { Asymp. Sig. (2- } \\
\text { sided) }\end{array}$ \\
\hline Pearson Chi-Square & $8.846^{\mathrm{a}}$ & 3 & .031 \\
Likelihood Ratio & 7.699 & 3 & .053 \\
Linear-by-Linear Association & .199 & 1 & .656 \\
N of Valid Cases & 40 & & \\
\hline
\end{tabular}

a. 5 cells $(62.5 \%)$ have expected count less than 5 . The minimum expected count is 40 .

According to the data, there is a significant relationship between the companies that have defined financial information system risk performance framework and metrics that are monitored and reported to management on a regular basis and effectiveness at optimization of controls. The chi-square value is 0.031 which is less than 0.05 at $5 \%$ significance level.

\begin{tabular}{|c|c|c|c|c|c|c|}
\hline & & \multicolumn{4}{|c|}{$\begin{array}{l}\text { Effectiveness of company at alignment with corporate risk } \\
\text { management? }\end{array}$} & \multirow[t]{2}{*}{ Total } \\
\hline & & $\begin{array}{l}\text { Highly } \\
\text { effective }\end{array}$ & Effective & $\begin{array}{l}\text { Moderately } \\
\text { effective }\end{array}$ & Ineffective & \\
\hline \multirow{4}{*}{$\begin{array}{l}\text { defined financial information system } \\
\text { risk performance framework and } \\
\text { metrics that are monitored and reported } \\
\text { to management on a regular basis }\end{array}$} & Count & 8 & 18 & 4 & 2 & 32 \\
\hline & $\%$ within yes & $100.0 \%$ & $75.0 \%$ & $100.0 \%$ & $50.0 \%$ & $80.0 \%$ \\
\hline & Count & 0 & 6 & 0 & 2 & 8 \\
\hline & $\%$ within no & $0.0 \%$ & $25.0 \%$ & $0.0 \%$ & $50.0 \%$ & $20.0 \%$ \\
\hline \multirow{2}{*}{ Total } & Count & 8 & 24 & 4 & 4 & 40 \\
\hline & & $100.0 \%$ & $100.0 \%$ & $100.0 \%$ & $100.0 \%$ & $100.0 \%$ \\
\hline
\end{tabular}

Chi-Square Tests 


\begin{tabular}{|l|l|l|l|}
\hline & Value & Df & $\begin{array}{l}\text { Asymp. Sig. (2- } \\
\text { sided) }\end{array}$ \\
\hline Pearson Chi-Square & $5.625^{\mathrm{a}}$ & 3 & .131 \\
Likelihood Ratio & 7.495 & 3 & .058 \\
Linear-by-Linear Association & 2.261 & 1 & .133 \\
N of Valid Cases & 40 & & \\
\hline
\end{tabular}

a. 6 cells $(75.0 \%)$ have expected count less than 5 . The minimum expected count is .80 .

The chi-square value is 0.131 , this is greater than 0.05 at $5 \%$ significance level. Hence, there is no significant relationship between companies that have defined financial information system risk performance framework and metrics that are monitored and reported to management on a regular basis and effectiveness of the company at alignment with corporate risk management.

Financial information system risk management, standards and leading practices

Which of the following standards or leading practices have you used in developing your financial information system risk framework and assessment processes?

\begin{tabular}{|l|l|l|}
\hline & Frequency & Percent \\
\hline COSO ERM - Committee of Sponsoring Organizations of the Treadway & 2 & 5.0 \\
\hline British Standard BS-6079-3:2000 & 10 & 25.0 \\
\hline COBRA - Consultative, Objective, and Bi-functional Risk Analysis & 4 & 10.0 \\
\hline IRAM - Information Risk Analysis Methodologies & 18 & 45.0 \\
\hline CRAMM - CCTA Risk Analysis and Management Method & 4 & 10.0 \\
\hline OCTAVE - Operationally Critical Threat, Asset, and Vulnerability Evaluation & 2 & 5.0 \\
\hline Total & 40 & 100.0 \\
\hline
\end{tabular}

Which of the following standards or leading practices has your company used in developing its information technology control framework and/or control library? Select all that apply.

Control framework/ or control library organizes and categorizes an organization's internal controls not only in a way that conforms to financial compliance regulations; but also ensure practices and procedures that are established create business value and minimize risk, as such its development is crucial to risk management.

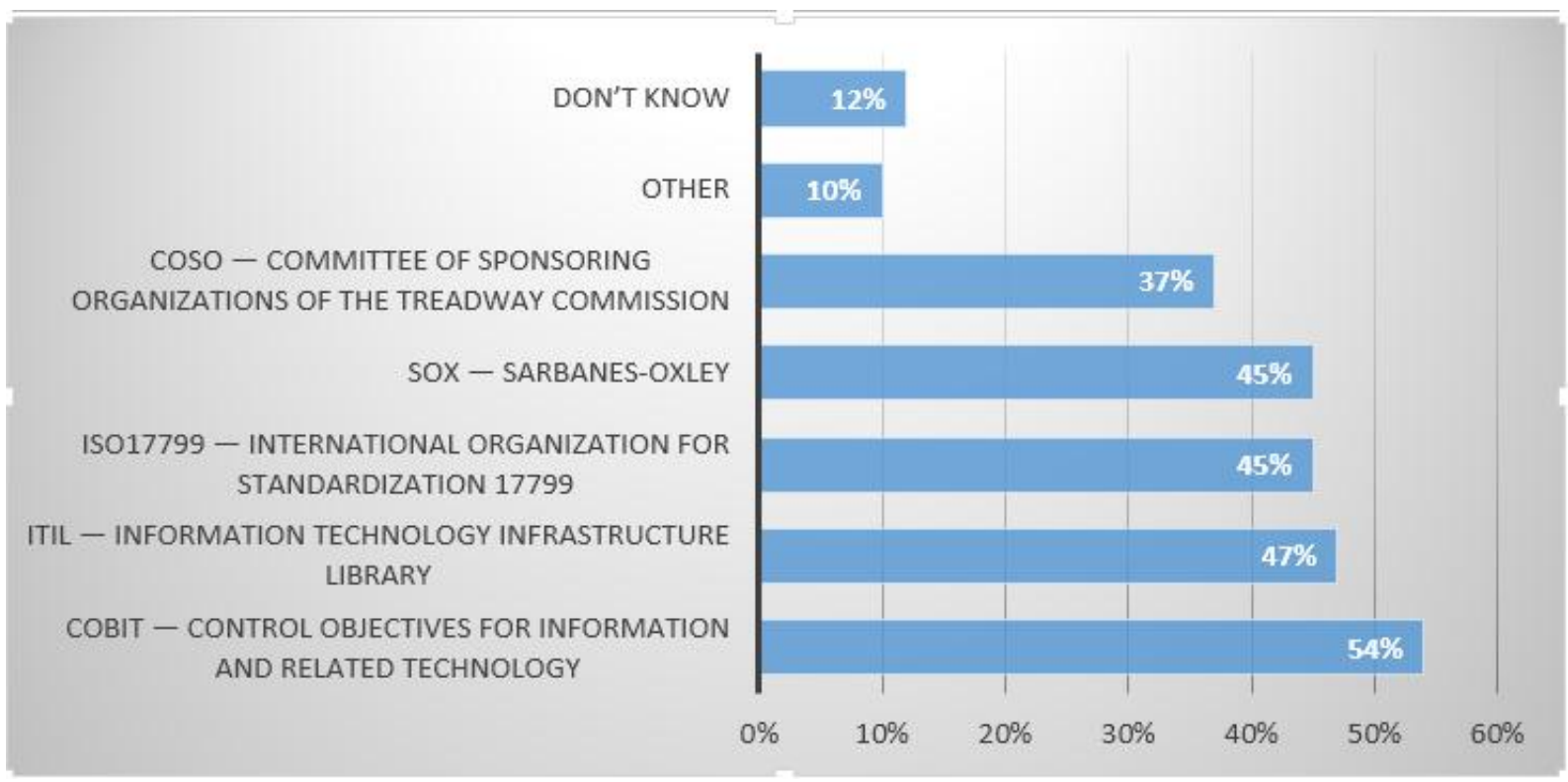

Do you agree that most of the risks faced by financial information systems would be better managed if they were handled during the development phases of the system?

\begin{tabular}{lll}
\hline & Frequency & Percent \\
\hline Strongly agree & 26 & 65.0 \\
Agree & 14 & 35.0 \\
Total & 40 & 100.0 \\
\hline
\end{tabular}

The respondents overwhelmingly agreed that most of the risks faced by financial information systems would be better managed if they were handled during the development phases of the system. 


\section{Conclusion}

It is evident that there are many risks facing information systems in the financial sector which is very sensitive. From the assessment, it is also clear that the financial institutions are not involved in the development of the systems and therefore the expertise in risk management issues is not taken into account by the developers. In conclusion, most of the risks facing these systems would be averted if at all the feedback and involvement of the financial institutions is taken into consideration starting from the initial stages of development methodology. This paper therefore proposes an all inclusive development process which incorporates risk assessment and analysis in each stage of development.

\section{References}

[1]. Bryman, A. and Bell, E. (2007), Business Research Methods, 2nd edition, Oxford UniversityPress.

[2]. Cooper, D.R., \& Schindler, P.S., (2008), Business Research Methods 8th edition,McGraw-Hill Companies, Inc.85

[3]. Creswell, J.W., (2008), Research Design: Qualitative, Quantitative and Mixed Methods Approach, Second Edition, Sage Publication, Inc.

[4]. Creswell, J.W. (2010).Research Design: Qualitative and Quantitative Approaches, Thousand Oaks, CA: Sage Publications.

[5]. Creswell, J.W. and Clark V.L. (2007). Designing and Conducting Mixed Methods Research, Thousand Oaks, CA: Sage Publications

[6]. Easterby-Smith, M., Thorpe, R. and Lowe, A. (2009) Management Research: AnIntroduction (2nd edn), London, Sage.

[7]. Eisner, E. W. (2009), Concerns and aspirations for qualitative research in the newmillennium, Qualitative Research, SAGE publications, London.

[8]. Feng N. and Xie J. (2011). A Bayesian networks-based security risk analysis model for information systems integrating the observed cases with expert experience. Scientific Research and Essays Vol. 7 (10), pp. 1103-1112. College of Management and Economics, Tianjin University, 300072 Tianjin, China.

[9]. Hart T. and Pollino A. (2009). Bayesian modelling for risk-based environmental water allocation. Canberra: National Water Commission.

[10]. Kumar, R., (2011), Research Methodology: A step by step guide for beginners, SagePublications Inc.

[11]. Lincoln, Y.S. and Guba, E.G. (2011) - Naturalistic Inquiry, Beverly Hills, CA: Sage Publications

[12]. Miles, B.M, \&Huberman, M.A., (2010), Qualitative Data Analysis, Second Edition, SagePublications, Inc.

[13]. Newman, I., \& Benz, C. (2011), Qualitative -Quantitative Research Methodology:exploring the Interactive Continuum, Printed in United State of America.

[14]. Saunders, M., Lewis, P., Thornhill, A., (2008) Research Methods for Business StudentsSecond Edition, UK, Financial Times, Prentice Hall

[15]. Saunders, M., Lewis, P.,\&Thornhill, A. (2009). Research Methods for Business Students: Pitman

[16]. Smith, J.K. (2011) - Quantitative versus Qualitative Research: An attempt to clarify the issue, Educational Researcher, 12 P. 6-13

[17]. Torkzadeh, G \& Doll, W. J. (2010), Test-retest reliability of the end-user computing satisfaction instrument. Decision Science, Vol.22, pp. 26-37. 